\title{
Anti-inflammatory and Anti-cancer Properties of $\beta$-Escin, a Triterpene Saponin
}

\author{
Jagan M. R. Patlolla • Chinthalapally V. Rao
}

Published online: 31 January 2015

(C) Springer International Publishing AG 2015

\begin{abstract}
Horse chestnut seed extract is well known for its antiedematous and anti-inflammatory medicinal properties. More recently, potential anti-carcinogenic properties have been described. $\beta$-Escin, a pentacyclic triterpene saponin with aglycone moieties, is the main active compound in horse chestnut seed extract. Here, we summarize the anti-cancer properties of $\beta$ escin in preclinical models, and its potential pharmacological use as an anti-inflammatory agent for the treatment of edema and chronic venous insufficiency. The major mechanisms for the anti-inflammatory activities are through modulation of eicosanoids and nuclear factor-kappa B (NF-kB). Anti-proliferation activities occur via induction of $\mathrm{p} 21$ and decreased expression of cyclin D1 and anti-apoptotic members of the Bcl-2 family of proteins. In addition, we discuss the clinical pharmacokinetics of $\beta$-escin and review the factors that determine its absorption, bioavailability, and distribution in animals. Despite the many beneficial effects of $\beta$-escin, it has been studied less extensively in models of cancer. Further studies are warranted to assess the usefulness of $\beta$-escin for cancer prevention and therapy.
\end{abstract}

Keywords $\beta$-Escin - Cancer prevention - Pharmacokinetics . Horse chestnut seed extract · Bioavailability

\section{Abbreviations \\ iNOS Inducible nitric oxide synthase \\ COX-2 Cyclooxygenase}

\section{This article is part of the Topical Collection on Cancer Chemoprevention}

J. M. R. Patlolla $\cdot$ C. V. Rao $(\bowtie)$

Center for Cancer Prevention and Drug Development, Department of Medicine, Hematology Oncology Section, Peggy and Charles

Stephenson Cancer Center, University of Oklahoma Health Sciences

Center, 975 NE 10th Street, BRC 1203, OUHSC, Oklahoma

City, OK 73104, USA

e-mail: cv-rao@ouhsc.edu

J. M. R. Patlolla

e-mail: jpatlolla@ouhsc.edu

$\begin{array}{ll}\text { NO } & \text { Nitric oxide } \\ \text { NF-kB } & \text { Nuclear factor-kB (NF-kB) } \\ \text { VEGF } & \text { Vascular endothelial growth factor } \\ \text { HCSE } & \text { Horse chestnut seed extract } \\ \text { IL-6 } & \text { Interleukin-6 } \\ \text { CVI } & \text { Chronic venous insufficiency } \\ \text { RIA } & \text { Radioimmunosorbent assay } \\ \text { IKK } & \text { IkappaB kinase complex } \\ \text { Stat3 } & \text { Signal transducer and activator of transcription 3 } \\ \text { JAK } & \text { Janus kinase 2 } \\ \text { TLR } & \text { Toll-like receptor } \\ \text { IL-1 } \beta & \text { Interleukin-1 } \beta \\ \text { TNF } & \text { Tumor necrosis factor } \\ \text { LPS } & \text { Lipopolysaccharide } \\ \text { ALDH } & \text { Aldehyde dehydrogenase } \\ \text { CL } & \text { Clearance } \\ \text { MRT } & \text { Mean residence time } \\ \text { LC } & \text { Liquid chromatography } \\ \text { MS } & \text { Mass spectrometry } \\ \text { Cdks } & \text { Cyclin dependent kinases } \\ \text { Rb } & \text { Retinoblastoma } \\ \text { CXC } & \text { Chemokine receptor kinase } \\ \text { CRPC } & \text { Castration-resistant prostate cancer }\end{array}$

\section{Introduction}

Millions of people die each year from chronic diseases, which are a global epidemic [1]. The elimination of risk factors to prevent any given chronic disease has had limited success in reducing the burden of diseases such as cancer, cardiovascular disease, and diabetes [2]. There has been considerable recent public and scientific interest in the use of phytochemicals derived from dietary components or traditional medicines to combat or 
prevent human diseases. Among the phytochemicals, triterpenoids are major components of medicinally used herbs and plant extracts [3]. Triterpenoids are metabolites of isopentenyl pyrophosphate oligomers and are ubiquitously distributed throughout the plant kingdom in the form of free triterpenoids, triterpenic glycosides (saponins), phytosterols, and/or their precursors.

Saponins The saponins are a vast group of glycoside compounds found abundantly in plant families like Sapindaceae, Aceraceae, Hippocastanaceae, Cucurbitaceae, and Araliaceae [4••]. Structurally, saponins are a class of secondary plant metabolites consisting of a sugar moiety glycosidically linked to a hydrophobic aglycone (sapogenin), which may be triterpene or steroidal $[4 \bullet \bullet, 5]$. Based on the nature of their aglycone skeleton, the saponins are classified into two groups. The first group consists of the steroidal saponins, which are almost exclusively present in monocotyledonous angiosperms [5]. The second group consists of the triterpenoid saponins, which occur in dicotyledonous angiosperms [6]. Some authors distinguish a third group, called steroidal amines or steroidal alkaloids. The aglycone (glycoside-free) portions of the saponins are termed sapogenins. The number of saccharide chains attached to the sapogenin/aglycone core can vary. The lipophilic aglycone can be any one of a wide variety of polycyclic organic structures originating from the serial addition of 10-carbon (C10) terpene units to compose a $\mathrm{C} 30$ triterpene skeleton [7], often with subsequent alteration to produce a $\mathrm{C} 27$ steroidal skeleton. Triterpenoid saponins have an aglycone triterpenoid C30 skeleton comprising a pentacyclic structure.

These triterpenoid saponins occur in a number of plant species, both wild and cultivated, that possess divergent biological activities [8-10]. They appear in different plant families and have been isolated from many species by numerous investigators (reviewed in Sprag et al.; 8). The genus Aesculus, commonly called the "buckeye", includes some of the most widely distributed plants in the Northern Hemisphere; this genus consists of 13-19 species that are currently found in eastern Asia, North America, and Europe [11]. Raven et al. [12] and Qiu et al. [13] have documented the North American origin of Aesculus and its family Hippocastanaceae, and their subsequent migration to other continents.

$\beta$-Escin Aescin, or escin, is a pentacyclic triterpene that exists in two series of $\alpha$ and $\beta$ isomers $[14,15 \cdot]$ defined by the position of an acetyl group at $\mathrm{C} 22$ and $\mathrm{C} 28$, respectively (Fig. 1 and Table 1). $\beta$-Escin, the major active component in extracts of horse chestnut seeds (HCSE), is primarily composed of escin Ia and escin Ib [27], while $\alpha$-escin is mainly composed of isoescin Ia and isoescin Ib. In the late nineties, Yoshikawa et al. isolated the bioactive triterpene oligoglycoside escins Ia, Ib, and IIIa, and isoescins Ia, Ib, and $\mathrm{V}$ from the seeds of the horse chestnut tree, and explained the structures based on the chemical and physicochemical evidence [28, 29]. Haralampidis et al. [30] reviewed the biosynthesis of triterpenoid saponins and addressed advances in the areas of the glycosylation of sapogenins and the cyclisation of 2,3-oxidosqualene. Here, we review reports from various investigators over the last two decades describing $\beta$-escin major, the active principle of Aesculus hippocastanum L. (Hippocastanaceae), focusing on its anti-carcinogenic activities in in vitro and in vivo studies.

\section{Medicinal Uses of $\beta$-Escin}

The use of $\beta$-escin as a folk medicine has been well documented. In China, $\beta$-escin has been used traditionally to prevent formation of gas in the gastrointestinal tract, promote the appetite and digestion of food, and as an antiseptic, antioxidant, analgesic, antipyretic, and anti-hemorrhoidal agent [31]. It has been reported previously to exhibit anti-edematous, anti-inflammatory, and anti-carcinogenic properties in various disease models [27]. Perhaps one of the most often prescribed uses is for the treatment of varicose veins and wound healing. It is now recognized that $\beta$-escin has some anti-cancer properties.

\section{In vitro Anti-cancer Properties of $\beta$-Escin}

The mode of action of $\beta$-escin varies considerably with the cell type, the concentration, and the time of treatment. Guo et al. [16] reported that $\beta$-escin can inhibit the growth of various tumor cell lines, including a human oral mucosal cell line (KB cells), and mouse liver cancer (H22) and sarcoma (S180) cell lines. We demonstrated that $\beta$-escin exhibits anticancer activity via the induction of p21 in human colon cancer cell lines HT-29 and HCT-116 [17••]. Studies have shown that induction of $\mathrm{p} 21 \mathrm{wafl} / \mathrm{cip} 1$ leads to reduced cell proliferation of mammalian cells and leads to binding of cyclin-dependent kinase (Cdk2) at amino acids residues 139-164, which are required by the cyclin $\mathrm{A}$ and $\mathrm{E}$ complex. $\beta$-Escin decreases phospho- $\mathrm{Rb}$ and cyclin A levels, leading to growth arrest of human colon cancer cells in the G1-S phase and inhibition of further progression and proliferation $[17 \bullet \cdot]$. The $\mathrm{Rb}$ (retinoblastoma) protein family contains important substrates of the Cdks, and is phosphorylated and dephosphorylated during the cell cycle. The hyperphosphorylated (inactive) form predominates in proliferating cells, whereas the 


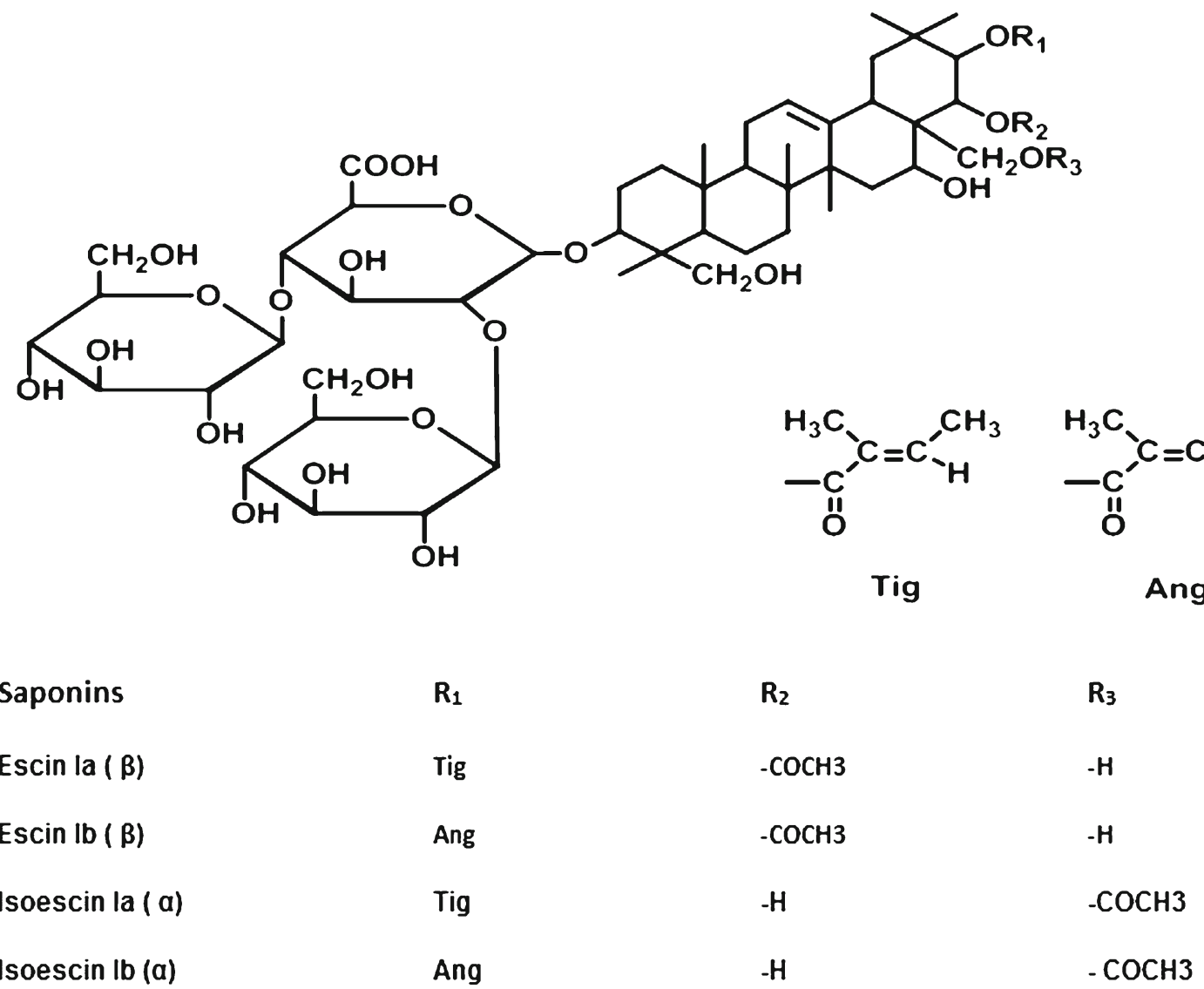

Fig. 1 Structure of $\beta$-escin (Figure is adapted from Wei F. et al., publication, Journal of Liquid Chromatography and Related Technologies, 2005; 28: 763-773)

hypophosphorylated (active) form is generally more abundant in quiescent or differentiating cells.

Later studies from other investigators revealed the anticancer properties of $\beta$-escin in different human cancer cell lines. Zhou et al. [18] demonstrated that $\beta$-escin regulates cell cycle progression through the induction of G1/S phase arrest accompanied by significant induction of apoptosis in HepG2 hepatocarcinoma cells. Harikumar et al. [19] reported that escin exhibits antitumor potential against KBM-5 human chronic myeloid leukemia, A293 human embryonic kidney carcinoma leukemia, H1299 human lung adenocarcinoma, Jurkat human T-cell leukemia, and U266 human multiple myeloma cell lines. They reported that Escin suppressed nuclear activation of nuclear factor-kappa B (NF- $\mathrm{KB})$ through inhibition of IkappaB kinase complex (IKK) alpha phosphorylation and degradation, and inhibition of IKK activation, leading to downregulation of NF-kB-regulated cell survival and abrogation of NF-kB-dependent reporter activity [19]. Piao et al. found that treatment of castration-resistant prostate cancer (CRPC) cells, PC-3, and DU-145 cells with $\beta$-escin induced G2/M cell cycle arrest with induction of p21, pro-apoptotic proteins like cleaved caspase-3, and poly adenosine diphosphate ribose polymerase (PARP). Tan et al. [21] found that treatment of human hepatocarcinoma HepG2 and PLC/PRF5 cells with $\beta$-escin suppressed constitutive and interleukin-6 (IL-6)-inducible signal transducer and activator of transcription 3 (STAT3) activation, and caused downregulation of STAT3-regulated genes, with associated inhibition of c-SRC, Janus kinase 2 (JAK2) activation, cyclin D1, Bcl-2, Bcl-xL, survivin, and vascular endothelial growth factor (VEGF).

A recent study by Ming et al. [22] also demonstrated the anti-cancer effects of $\beta$-escin in human hepatocellular carcinoma cells. They showed that $\beta$-escin could inhibit proliferation and substantially enhance cytotoxicity of paclitaxel and doxorubicin by downregulating cyclin D1, Bcl-2, Bcl-xL, survivin, and VEGF. Shen et al. [23] reported that treatment of human cholangiocarcinoma cell lines QBC939, Sk-ChA-1, and MZ-ChA-1 with $\beta$-escin induces growth arrest and increases apoptosis with collapse of the mitochondrial membrane potential and the activation of the caspase- 3 pathway. Ji et al. [24] showed that $\beta$-escin inhibits nitric oxide (NO) production and growth of A549 human lung cancer cells by suppressing the JAK/STAT/inducible nitric oxide (iNOS) signaling pathway. Wang et al. [25•] revealed that $\beta$-escin can potentiate the anti-cancer effect of gemcitabine in pancreatic cancer cell lines.

Numerous proteins, including c-myc, cyclin D1, Bcl-2, COX-2, Bcl-xL, and survivin, are regulated by NF-kB at the 
Table 1 Anticancer effects of $\beta$-Escin in vitro and in vivo studies

\begin{tabular}{|c|c|c|c|}
\hline Type of cancer & Organ site/cell lines or animal model & $\begin{array}{l}\text { Molecular markers } \\
\downarrow \text { inhibition } \\
\uparrow \text { induction }\end{array}$ & Reference (\#) \\
\hline \multicolumn{4}{|l|}{ In vitro studies } \\
\hline $\begin{array}{l}\text { 1) Human oral, mice liver } \\
\text { cancer and sarcoma cell line }\end{array}$ & $\begin{array}{l}\text { KB cells(human Oral) } \\
\text { H22 and S180 (Mice) }\end{array}$ & Growth & Guo et al. [16] \\
\hline 2) Human colon cancer & HT-29, HCT-116 & $\begin{array}{l}\uparrow \mathrm{pRB}, \text { cyclins } \mathrm{A} \text { and } \mathrm{E} \\
\uparrow \mathrm{p} 21 \text {, apoptosis }\end{array}$ & Patlolla et al. $[17 \bullet \bullet]$ \\
\hline 3) Hepatocarcinoma & HepG2 & $\begin{array}{l}\downarrow \mathrm{G} 1 / \mathrm{S} \text { phase } \\
\uparrow \text { apoptosis }\end{array}$ & Zhou et al. [18] \\
\hline 4) Human tumor cells & $\begin{array}{l}\text { KBM-5, A293, H1299 } \\
\text { Jurkat, U266 }\end{array}$ & $\begin{array}{l}\downarrow \text { COX-2, IAP-2, ICAM-1, MMP-9 } \\
\text { VEGF, Bcl-2, Cyclin-D1, Nf-KB, IKK- } \gamma\end{array}$ & Harikumar et al. [19] \\
\hline 5) Human prostate cancer cells & CRPC, PC-3 and DU-145 & $\begin{array}{l}\downarrow \text { Bcl-2, Bcl-xL, xIAP, cIAP1 } \\
\uparrow \text { Apoptosis, G2/M arrest }\end{array}$ & Piao et al. [20] \\
\hline 6) Human hepatocarcinoma & HepG2, PLC/PRF5 & $\begin{array}{l}\downarrow \text { STAT-3, c-SRC, JAK2, Cyclin D1, Bcl-2, } \\
\text { Bcl-xL, Survivin and VEGF }\end{array}$ & Tan et al. [21] \\
\hline 7) Human hepatocarcinoma & SMMC-7721 & $\begin{array}{l}\uparrow \text { Caspase- } 3,9 \text { and } 8 \text { activity } \\
\text { Bcl-2 }\end{array}$ & Ming et al. [22] \\
\hline 8) Human cholangiocarcinoma & QBC939, Sk-ChA-1, and MZ-ChA-1 & $\begin{array}{l}\downarrow \mathrm{G} 1 / \mathrm{S} \text { and } \mathrm{G} 2 \mathrm{M} \text { phases } \\
\downarrow \text { caspase- } 3 \text { activity }\end{array}$ & Shen et al. [23] \\
\hline 9) Lung carcinoma & A549 & iNOS, JAK, STAT $1 \& 3$ p38 MAPK & Ji DB et al. [24] \\
\hline 10) Human pancreatic cancer & BxPC-3 \& Panc-1 & $\begin{array}{l}\downarrow c-M y c, \text { COX-2, cyclin D1, survivin, } \\
\text { Bcl- } 2 \text { and Bcl-xL } \\
\uparrow \text { caspase-3 activity }\end{array}$ & Wang YW et al. [25•] \\
\hline 11) Human lung cancer & $\mathrm{H} 460$ & $\begin{array}{l}\uparrow \text { Aldh1A1, RhoA, Rock } \\
\downarrow \mathrm{p} 21\end{array}$ & Patlolla et al. [26•] \\
\hline \multicolumn{4}{|l|}{ In vivo studies } \\
\hline 1) Colon cancer & $\begin{array}{l}\text { AOM induced ACF, Formation in } \\
\text { F344 rats }\end{array}$ & $\downarrow$ Preneoplastic lesions, ACF formation & Patlolla et al. $[17 \bullet \bullet]$ \\
\hline 2) Hepatocarcinoma & H22 tumors on nude mice & $\downarrow 43.5 \%$ tumor inhibition & Zhou et al. [18] \\
\hline 3) Human pancreatic cancer & BxPC-3 nude mice & $\downarrow$ Reduced tumor volume & Wang YW et al. [25•] \\
\hline 4) Human lung cancer & NNK induced lung cancer in $\mathrm{A} / \mathrm{J}$ mice & $\downarrow 40-53 \%$ lung tumor inhibition & Patlolla et al. [26•] \\
\hline
\end{tabular}

transcriptional level and are linked to chemo-resistance [32-35]. Wang et al. [25•] examined the effect of escin alone or in combination with gemcitabine on the expression of the NF-kB-regulated gene products implicated in cell proliferation, c-myc, cyclin D1, and cyclooxygenase-2 (COX-2), and antiapoptosis, Bcl-2, Bcl-xL, and survivin. They found that the combination downregulated the constitutive expression of c-myc, cyclin D1, Bcl-2, COX-2, Bcl-xL, and survivin in BxPC-3 and PANC-1 human pancreatic cancer cells. Recently, Rammon et al. [36] showed that a combination of Escin with gemcitabine or cisplastin resulted in a significant cytotoxic effect in PANC-1 human pancreatic cells, inducing apoptosis and downregulating the NF-kB signaling pathway [36].

Recently, Guney et al. [37] found that $\beta$-escin had potent antiproliferative effects on H-Ras 5RP7 cells, and increased vacuolization and chromatin condensation compared with control, as assessed with transmission electron microscopy [37]. We recently found that treatment of the H460 human lung cancer cell line with different concentrations of $\beta$-escin $(0-40 \mu \mathrm{M})$ induced p21 levels, suppressed Rho A and Rock protein expression, and caused a significant reduction $(\sim 60-85 \%)$ in the subpopulation of cells with elevated aldehyde dehydrogenase (ALDH) activity [26•].

From these reports, it is clear that $\beta$-escin has a number of anti-cancer activities, including induction of cell cycle arrest and apoptosis, against several human cancer cell lines [16, $17 \bullet \bullet, 18,23]$. $\beta$-Escin has been shown to exhibit significant anti-proliferative activity by inhibiting transcription factors that are involved in various signaling pathways, like JAK, STAT, NFkB, and activator protein-1 (AP-1), in different cell lines $[19,21,24,25 \bullet]$. Studies have shown that $\beta$-escin prompts apoptosis [17••] by inducing the cleavage of caspase- 3 and caspase- 8 [23] and modulating the expression levels of $\mathrm{Bcl}-2$ and $\mathrm{Bcl}-\mathrm{xL}$ family members [25•]. These events are preceded by the generation of reactive oxygen species (ROS; 29). Recently, Lee et al. [38] showed the potential impact of $\beta$-escin in inhibiting AGS human gastric cancer cells' migration and invasion by modulating the CXC motif chemokine receptor CXCL16/CXCR axis [38]. 


\section{In vivo Anti-cancer Effects of $\beta$-Escin}

The anti-carcinogenic activities of $\beta$-escin have been established in animal models of some cancers. We have shown a dose-dependent chemopreventive effect of $\beta$-escin ( 250 and $500 \mathrm{ppm}$ ) on the formation of azoxymethane (AOM)-induced colonic aberrant crypt foci (ACF) containing four or more aberrant crypts in F344 rats [17••]. The potential antitumor activity of $\beta$-escin was evaluated by Zhou et al. [18] in hepatocellular carcinoma in vivo. At a dose of $2.8 \mathrm{mg} / \mathrm{kg}$, escin caused a $43.5 \%$ inhibition of $\mathrm{H} 22$ tumor growth in mice. Wang et al. [25 ] observed that escin augmented the therapeutic effect of gemcitabine in xenografts of the BxPC-3 cell line in nude mice. Tumors were established by subcutaneous injection of $5 \times 10^{6} \mathrm{BxPC}-3$ cells into the flanks of six-week-old nude mice. When tumors reached a mean volume of $120 \mathrm{~mm}^{3}$, the mice were injected IP with $2 \mathrm{mg} / \mathrm{kg}$ of $\beta$-escin once daily and $/$ or $100 \mathrm{mg} / \mathrm{kg}$ gemcitabine twice weekly. A significant reduction of tumor volume $\left(251.9 \pm 43.8 \mathrm{~mm}^{3}\right)$ was observed in the group receiving the combination therapy, compared with the control group $\left(536.1 \pm 59.3 \mathrm{~mm}^{3}\right)$ or the groups given either agent alone. Recently, we found that administration of $500 \mathrm{ppm}$ of $\beta$-escin significantly suppressed formation of 4-(methylnitrosamino)-1-(3-pyridyl)-1-butanone NNKinduced lung adenoma and adenocarcinoma formation in female $\mathrm{A} / \mathrm{J}$ mice by $>40 \%$ at 20 weeks, and by $53.3 \%$ $(p<0.0001)$ at 36 weeks of age [26•]. The above studies clearly support the potential chemopreventive properties of naturally occurring $\beta$-escin. Thus, it will be important to carry out further studies to establish the optimal dose range and the efficacy of $\beta$-escin in various animal models of adenocarcinoma.

\section{Pharmacokinetics and Pharmacodynamics of $\beta$-Escin in Animals}

Some studies on the absorption, distribution, metabolism, and excretion of $\beta$-escin in rodents have been conducted. Among these, some findings support the notion that $\beta$-Escin undergoes a rapid and efficient metabolism that severely curtails the availability of the parent compound. Previously, it was shown that escin 1a undergoes extensive metabolism into isoescin Ia, desacylescin I, 21ß-O-tigloylprotoaescigenin, and protoaescigenin by enzymes of human intestinal bacteria, including Lactobacillus brevis [39]. Desacylescin I showed potential inhibitory effects on the growth of mouse sarcoma180 , hepatic carcinoma $\mathrm{H} 22$, and lung carcinoma in vitro. Wu et al. [40••] investigated the pharmacokinetics of escin Ia and isoescin Ia in the rat, with a particular focus on their interconversion. Rats were injected with $1.7 \mathrm{mg} / \mathrm{kg}$ of a sodium escinate solution containing $0.5 \mathrm{mg} / \mathrm{kg}$ escin Ia and $0.5 \mathrm{mg} / \mathrm{kg}$ isoescin Ia via the tail vein and an IV $(0.5 \mathrm{mg} / \mathrm{kg}$ via the tail vein) or oral (4 mg/kg by gavage) dose of pure escin Ia or isoescin Ia solution. The clearance (CL; drug amount eliminated per unit of time/drug concentration in plasma) values for escin Ia and isoescin Ia were 726 and $207 \mathrm{ml} / \mathrm{min}$, respectively. This exceeds the hepatic blood flow, due to significant firstpass metabolism in the gut [40••], further supporting the previous studies of Yang et al. [39] that showed extensive metabolism in the gut and low bioavailability of escin isomers. The $t_{1 / 2}$ and mean residence time MRT values for sodium escinate were significantly higher than those for the individual escin Ia and isoescin Ia isomers $(P<0.05)$. Thus, the combination found in herbal preparations may be superior to individual isomers in prolonging the duration of action of escin in vivo $[40 \bullet \cdot]$. Bidirectional interconversion of the isomers was found to occur, with the conversion of escin Ia to isoescin Ia being much faster than the reverse reaction. The mechanism of this trans-esterification reaction in vivo, that is, whether it is chemically or enzymatically mediated, requires further study. Whether such a superior benefit will actually translate to humans must also be determined. Further studies using radiolabeled tracers are needed to fully evaluate the tissue distribution, metabolism, absorption, and excretion of $\beta$-escin.

\section{Clinical Pharmacokinetics of $\beta$-Escin}

In China, escin has been widely used in clinical settings to prevent inflammatory edema after trauma, such as fracture and surgery [41-43]. A few studies on the pharmacokinetics of $\beta$ escin and escin-containing extracts in humans have been conducted. Pabst et al. [44] reported that topical application of $1 \%$ or $2 \%$ escin to individuals with sports injuries was well tolerated and resolved spontaneous pain better than placebo. Montenegro et al. [45] carried out an in vitro skin permeation study on the feasibility of using escin in aqueous solutions and gels. Using a solid phase extraction method vs. conventional HPLC procedures, they determined the maximum amount of escin that diffused through the skin. Schrader et al. [46] used a radioimmunosorbent assay (RIA) to compare the relative oral bioavailability of $\beta$-escin from a sugar-coated tablet formulation (CAS 11072-93-8) to that from a reference preparation in 18 healthy male volunteers over a 48 -h period. They found that the test preparation exceeded the maximum bioavailability of the reference preparation without adverse side effects.

Although it is well established that escin is the active principle in HCSE, Lowe D et al. [47] used an RIA method and observed heterogeneity in the bioavailability and pharmacokinetic data with $\beta$-escin from different extracts, and between different preparations from the same extract. When considering commercial preparations of HCSE available around the world, knowing the ratio of $\alpha$ - to $\beta$-escin is essential. Clinical trials were used to estimate the total $\beta$-escin in biosamples in 
the past, since the available analytical methods were limited and hampered resolution of the individual $\alpha$ - and $\beta$-escins. In order to assay the individual escins and to better characterize the clinical pharmacokinetics and other properties in biosamples, a specific and sensitive liquid chromatography (LC)-mass spectrometry (MS)/MS method has been developed and validated for the simultaneous quantification of escin Ia and escin Ib in human plasma [48, 49]. The assay is characterized by simple sample preparation and greater sensitivity than the RIA method. It has a lower limit of quantitation of $33 \mathrm{pg} / \mathrm{ml}$ for each saponin, compared with $0.5 \mathrm{ng} / \mathrm{mL}$ for total escin.

Li et al. [48] assessed the plasma concentrations of escin Ia and escin $\mathrm{Ib}$ in a clinical trial in which 10 healthy male volunteers received a single intravenous infusion of sodium escinate containing $10 \mathrm{mg}$ of escin saponins, including $3.0 \mathrm{mg}$ escin Ia and $2.0 \mathrm{mg}$ escin $\mathrm{Ib}$. They found that the pharmacokinetics of escin Ia and escin Ib were significantly different from those of the total $\beta$-escin reported previously [46, 50]. Later, Wu et al. [49] carried out a study with 10 healthy male volunteers aged 20-30 years with body mass index indexes (BMI) of 20-24. Participants were given a single oral dose of two sodium escinate tablets, each tablet containing $30 \mathrm{mg}$ of escin saponins of different escins with 9.3, $5.7,8.4$, and $3.6 \mathrm{mg}$ of escin $\mathrm{Ia}$, escin $\mathrm{Ib}$, isoescin $\mathrm{Ia}$, and isoescin $\mathrm{Ib}$, with $250-\mathrm{mL}$ water. They detected the four saponins in human plasma for $36 \mathrm{~h}$ after a single oral dose of sodium escinate, with the peak concentrations of the four saponins in the range of $0.38-1.8 \mathrm{ng} / \mathrm{mL}$ at approximately $2 \mathrm{~h}$ after dosing. They also found that $\beta$-escins cleared from human plasma more rapidly than $\alpha$-escins. The maximal plasma concentrations ( $\mathrm{Cmax}$ ) for each of the isomers observed in this study (in $\mathrm{ng} / \mathrm{mL}$ ) were 0.77 \pm 0.64 for escin Ia, $0.38 \pm 0.26$ for escin $\mathrm{Ib}, 1.82 \pm 1.60$ for isoescin Ia, and $0.74 \pm 0.73$ for isoescin Ib. In order to develop $\beta$-escin for use as a pure drug, detailed studies of its absorption, distribution, metabolism, excretion, and pharmacokinetics are needed.

\section{Clinical Uses of $\beta$-Escin}

$\beta$-Escin has been traditionally used to treat conditions such as chronic venous insufficiency [51-54], inflammation [31], hemorrhoids [55], edema, elevated glucose [28, 56], obesity [57], and cerebral ischemic damage [58], and in clinical trials in patients with HIV-1 [59]. HCSE is widely used in Europe for chronic venous insufficiency (CVI), a syndrome characterized by lower extremity edema and varicosities [51-54]. The antiinflammatory effects of $\beta$-escin are mainly attributable to its anti-histaminic and anti-serotoninergic activities [31]. $\beta$-Escin dose-dependently enhanced hypoxia- induced activation of human endothelial cells and caused inhibition of phospholipase A2, an enzyme responsible for the release of precursors of inflammatory mediators [60]. Recently, Liu et al. [61] observed the in vitro effects of escin on the inflammatory reaction of human periodontal ligament cells, finding a significant blockade of the expression of Toll-like receptor (TLR)2 and decreased pro-inflammatory cytokines interleukin-1 $\beta$ (IL- $1 \beta$ ), tumor necrosis factor- $\alpha$ (TNF- $\alpha$ ), and IL-6 induced by lipopolysaccharide (LPS; 62). A recent study showed that escin has a potent protective effect on LPS-induced acute lung injury by inhibiting the inflammatory response [62]. Escin also exerts synergistic anti-inflammatory effects with glucocorticoids [63]. In addition, escin significantly inhibited NF-KB activation and downregulated the expression of TNF- $\alpha$, alleviating brain edema in rats with traumatic brain injuries [64]. A recent study demonstrated that $\beta$-escin has strong anti-allergic properties [65•]. Although most of these experiments have shown the anti-inflammatory effects of $\beta$-escin, there are no studies of the effects of $\beta$-escin on inflammation in animal models of carcinogen-induced cancers.

\section{Concluding Remarks and Future Prospects}

Several studies have examined the benefits of $\beta$-escin. The initial evidence supporting the anticancer effects of $\beta$-escin come from a number of in vitro studies, which report a significant downregulation of cyclin D, NF-kB, STAT3, AP-1, and several anti-apoptotic proteins, including $\mathrm{Bcl} 2, \mathrm{Bcl}-\mathrm{xL}$, and survivin. The few preclinical trials conducted in animal models of cancer showed that $\beta$-escin has protective and antitumor properties. Moreover, $\beta$-escin has been shown to be nontoxic in large doses, even at $500 \mathrm{mg} / \mathrm{kg}$ body weight. The ability of $\beta$-escin to affect gene transcription and to induce apoptosis in malignant cells supports its potential for cancer chemoprevention and justifies further investigation in drug development programs. It is essential to understand the mechanisms by which $\beta$-escin acts on the molecular level to inhibit the carcinogenic process. Given the potential of $\beta$-escin as an anti-cancer agent, future studies should focus on detailed preclinical toxicity, bioavailability, pharmacodynamics, tissue distribution, and extensive evaluation of tumor inhibition using adenoma and adenocarcinoma as efficacy end points, before undertaking extensive clinical trials. Later research should examine the synthesis and development of analogs that might prove useful for human clinical studies.

Acknowledgments The authors are thankful to Dr. Julie Sando and Mrs. Kyler Kathy for valuable suggestions and editorial help with the manuscript. 


\section{Compliance with Ethics Guidelines}

Conflict of Interest Jagan M. R. Patlolla and Chinthalapally V. Rao declare that they have no conflict of interest.

Human and Animal Rights and Informed Consent This article does not contain any studies with human or animal subjects performed by any of the authors.

\section{References}

Papers of particular interest, published recently, have been highlighted as:

- Of importance

•- Of major importance

1. World Health Organization. Health Report, 2006. Lyon: WHO Publications Press; 2006.

2. Chronic Disease Prevention. Center for Disease Control, Annual Report (2006).

3. Patlolla JM, Rao CV. Triterpenoids for cancer prevention and treatment: current status and future prospects. Curr Pharm Biotechnol. 2012;13(1):147-55.

4.• Rao AV, Gurfinkel DM. The bioactivity of saponins: triterpenoid and steroidal glycosides. Drug Metabol Drug Interact. 2000;17(14):211-35. This review summarizes the saponins chemistry, metabolism and in role in different diseases.

5. Challinor VL, De Voss JJ. Open-chain steroidal glycosides, a diverse class of plant saponins. Nat Prod Rep. 2013;30(3):429-54.

6. Bruneton J. Pharmacognosy, Phytochemistry, Medicinal Plants. Lavoisier Publishing, Paris, 1995; pp. 538-544 (ISBN 2-47300028-7).

7. Project Summary: Functional Genomics of Triterpene Saponin Biosynthesis in Medicago Truncatula. "http://www.noble.org/ Plantbio/Dixon/Personnel/projectsummaries/Saponin.html

8. Sparg SG, Light ME, van Staden J. Biological activities and distribution of plant saponins. J Ethnopharmacol. 2004;94:219-43.

9. De Geyter E, Lambert E, Geelen D, Smagghe G. Novel advances with plant saponins as natural insecticides to control pest insects. Pest Tech. 2007;2:96-105.

10. Vincken JP, Heng L, de Groot A, Gruppen H. Saponins, classification and occurrence in the plant kingdom. Phytochemistry. 2007;68(3):275-97.

11. Hardin JW. A revision of the American Hippocastanaceae. Brittonia. 1957;9:145-71

12. Raven PH, Axelrod KI. Angiosperm biogeography and past continental movements. Ann Mo Bot Gard. 1974;61:539-673.

13. Xiang Q-Y, Crawford DJ, Wolfe AD, Tang Y-C, DePamphilis CW. Origin and biogeography of Aesculus L. (Hippocastanaceae): a molecular phylogenetic perspective. Evolution. 1998;52(4):988-97.

14. Griffini A, Lolla E, Petrlongo F. Liquid chromatographythermospray mass spectrometry analysis of $\beta$-escin. Fitoterapia. 1997;68:520-6.

15. Wei F, Mal LY, Cheng XL, Lin RCH. Preparative HPLC for purification of four isomeric bioactive saponins from the seeds of Aesculus chinensis. J Liq Chromatogr Relat Technol. 2005;28: 763-73. In this paper a detailed methodology for isolation and purification of isomeric escins from crude extracts of aesculus plants have been reported.
16. Guo W, Xu B, Yang XW, Liu Q, Cui JR. The anticancer effect of $\beta$ escin sodium. Chin Pharmacol Bull. 2003;19:351-2.

17.• Patlolla JM, Raju J, Swamy MV, Rao CV. Beta-escin inhibits colonic aberrant crypt foci formation in rats and regulates the cell cycle growth by inducing p21 (wafl/cip1) in colon cancer cells. Mol Cancer Ther. 2006;5(6):1459-66. This paper for the first time demonstrates the functional characterization of $\beta$-Escin's antiproliferation characteristics which decreased the phosphorylation of retinoblastoma protein in colon cancer cells and in an experimental colon cancer pre-clinical animal model.

18. Zhou XY, Fu FH, Li Z, Dong QJ, He J, Wang CH. Escin, a natural mixture of triterpene saponins, exhibits antitumor activity against hepatocellular carcinoma. Planta Med. 2009;75:1580-5.

19. Harikumar KB, Sung B, Pandey MK, Guha S, Krishnan S, Aggarwal BB. Escin, a pentacyclic triterpene, chemosensitizes human tumor cells through inhibition of nuclear factor-kappaB signaling pathway. Mol Pharmacol. 2010;77(5):818-27.

20. Piao S, Kang M, Lee YJ, Choi WS, Chun YS, Kwak C, Kim HH. Cytotoxic Effects of Escin on Human Castration-resistant Prostate Cancer Cells Through the Induction of Apoptosis and G2/M Cell Cycle Arrest. Urology, 2014; pjj: S0090-4295(14) 00631-1.

21. Tan SM, Li F, Rajendran P, Kumar AP, Hui KM, Sethi G. Identification of $\beta$-escin as a novel inhibitor of signal transducer and activator of transcription 3/Janus-activated kinase 2 signaling pathway that suppresses proliferation and induces apoptosis in human hepatocellular carcinoma cells. J Pharmacol Exp Ther. 2010;334(1):285-93.

22. Ming ZJ, Hu Y, Qiu YH, Cao L, Zhang XG. Synergistic effects of beta-aescin and 5-fluorouracil in human hepatocellular carcinoma SMMC-7721 cells. Phytomedicine. 2010;17(8):575-80.

23. Shen DY, Kang JH, Song W, Zhang WQ, Li WG, Zhao Y, et al. Apoptosis of human cholangiocarcinoma cell lines induced by $\beta$ escin through mitochondrial caspase-dependent pathway. Phytother Res. 2011;25(10):1519-26.

24. Ji DB, Xu B, Liu JT, Ran FX, Cui JR. $\beta$-escin sodium inhibits inducible nitric oxide synthase expression via downregulation of the JAK/STAT pathway in A549 cells. Mol Carcinog. 2011;50(12):945-60.

25. Wang YW, Wang SJ, Zhou YN, Pan SH, Sun B. Escin augments the efficacy of gemcitabine through down-regulation of nuclear factor$\mathrm{kB}$ and nuclear factor-kB-regulated gene products in pancreatic cancer both in vitro and in vivo. J Cancer Res Clin Oncol. 2012;138(5):785-97. In this paper $\beta$-Escin in combination with gemcitabine increases anti-tumor activity and chemotherapeutic activity of gemcitabine against Pancreatic cancer which is an aggressive malignancy in present day condition.

26. Patlolla JM, Qian L, Biddick L, Zhang Y, Desai D, Amin S, et al. $\beta$ Escin inhibits NNK-induced lung adenocarcinoma and ALDH1A1 and RhoA/ROCK expression in A/J mice and growth of $\mathrm{H} 460$ human lung cancer cells. Cancer Prev Res. 2013;6(10):1140-9. This paper demonstrates for the first time the efficacy of $\beta$-Escin in chemoprevention of lung cancer using A/J mouse lung tumour bioassay and also against stem cell marker.

27. Sirtori A. Pharmacology, pharmacokinetics and therapeutics profile. Pharmacol Res. 2001;44(3):183-93.

28. Yoshikawa M, Murakami T, Matsuda H, Yamahara J, Murakami N, Kitagawa I. Bioactive saponins and glycosides. III. Horse chestnut (1): the Structures, inhibitory effects on ethanol absorption, and hypoglycemic activity of escins Ia, Ib, IIa, IIb, and IIIa from the seeds of Aesculus hippocastanum L. Chem Pharm Bull. 1996;44(8):1454-64.

29. Yoshikawa M, Murakami T, Yamahara J, Matsuda H. Bioactive saponins and glycosides. XII. Horse chestnut. (2): structures of escins IIIb, IV, V, and VI and isoescins Ia, Ib, and V, acylated polyhydroxyoleanene triterpene oligoglycosides, from the seeds 
of horse chestnut tree (Aesculus hippocastanum L., Hippocastanaceae). Chem Pharm Bull. 1998;46(11):1764-9.

30. Haralampidis K, Trojanowska M, Osbourn AE. Biosynthesis of triterpenoid saponins in plants. Adv Biochem Eng Biotechnol. 2002;75:31-49.

31. Matsuda H, Li Y, Muakami T, Ningmiya K, Yamahara I, Yoshikawa M. Effects of escins Ia, Ib, Ila, Iib from horse chestnut, the seeds of Aesculus hippocastanum L., on acute inflammation in animals. Biol Pharm Bull. 1997;20(10):1092-5.

32. Li Y, Ahmed F, Ali S, Philip PA, Kucuk O, Sarkar FH. Inactivation of nuclear factor kappaB by soy isoXavone genistein contributes to increased apoptosis induced by chemotherapeutic agents in human cancer cells. Cancer Res. 2005;65(15):6934- 42.

33. Tamm I, Kornblau SM, Segall H, Krajewski S, Welsh K, Kitada S, et al. Expression and prognostic signiWcance of IAP-family genes in human cancers and myeloid leukemias. Clin Cancer Res. 2000;6(5):1796-803.

34. Bai J, Sui J, Demirjian A, Vollmer Jr CM, Marasco W, Callery MP. Predominant Bcl-XL knockdown disables antiapoptotic mechanisms: tumor necrosis factor-related apoptosis-inducing ligand-based triple chemotherapy overcomes chemoresistance in pancreatic cancer cells in vitro. Cancer Res. 2005;65(6): 2344-52.

35. El-Rayes BF, Ali S, Ali IF, Philip PA, Abbruzzese J, Sarkar FH. Potentiation of the effect of erlotinib by genistein in pancreatic cancer: the role of Akt and nuclear factor-kappaB. Cancer Res. 2006;66(21):10553-9.

36. Rimmon A, Vexler A, Berkovich L, Earon G, Ron I, Lev-Ari S. Escin chemosensitizes human pancreatic cancer cells and inhibits the nuclear factor-kappaB signaling pathway. Biochem Res Int. 2013. doi: $10.1155 / 2013 / 251752$.

37. Guney G, Kutlu HM, Iscan A. The apoptotic effects of escin in the H-Ras transformed 5RP7 cell line. Phytother Res. 2012;27(6): 900-5.

38. Lee HS, Hong JE, Kim EJ, Kim SH. Escin suppresses migration and invasion involving the alteration of CXCL16/CXCR6 axis in human gastric adenocarcinoma AGS cells. Nutr Cancer. 2014;66(6):938-45.

39. Yang XW, Zhao J, Cui JR, Guo W. Studies on the biotransformation of escin Ia by human intestinal bacteria and the anti-tumor activities of desacylescin 1. Beijing Da Xue Bao. 2004;36(1):31-5.

40.• Wu XJ, Zhang ML, Cui XY, Gao F, He Q, Li XJ, et al. Comparative pharmacokinetics and bioavailability of escin Ia and isoescin Ia after administration of escin and of pure escin Ia and isoescin Ia in rat. J Ethnopharmacol. 2012;139(1):201-6. This paper summarizes the pharmacokinetic and bioavailability of different isomers of escin extracted from horsechestnut seed and from that of pure escin.

41. Ma CF, Li L. Clinical observation of the curative effects of a combination of sodium aescinate and glycerol fructose on joint swelling after calcaneal fracture. Chin Pharm. 2008;11:445-6.

42. Tang L. Clinical observation of the curative effects of sodium aescinate on swelling after ankle fracture. Mod Med J. 2008;36:105-6.

43. Yang LD, Liu F. Clinical observation of the curative effects of sodium aescinate on limb swelling resulting from fracture of tibia and fibula. Acta Acad Med Nantong. 2009;29:34-5.

44. Pabst H, Segesser B, Bulitta M, Wetzel D, Bertram S. Efficacy and tolerability of escin/diethylamine salicylate combination gels in patients with blunt injuries of the extremities. Int J Sports Med. 2001;22(6):430-6.

45. Montenegro L, Carbone C, Giannone I, Puglisi G. Use of solid phase extraction(SPE) to evaluate in vitro skin permeation of aescin. Pharmazie. 2007;62(5):342-5.

46. Schrader E, Schwankl W, Sieder C, Christoffel V. Comparison of the bioavailability of beta-aescin after single oral administration of two different drug formulations containing an extract of horsechestnut seeds. Pharmazie. 1995;50:623-7.

47. Loew D, Schrodter A, Schwankl W, Marz RW. Measurement of the bioavailability of aescin-containing extracts. Methods Find Exp Clin Pharmacol. 2000;22:537-42.

48. Liu L, Wu X, Wu D, Wang Y, Li P, Sun Y, et al. A liquid chromatography-tandem mass spectrometry method for the simultaneous quantification of escin Ia and escin IB in human plasma: application to a pharmacokinetic study after intravenous administration. Biomed Chromatogr. 2010;24(12):1309-15.

49. Wu X, Liu L, Zhang M, Wu D, Wang Y, Sun Y, et al. Simultaneous analysis of isomers of escin saponins in human plasma by liquid chromatography-tandem mass spectrometry: application to a pharmacokinetic study after oral administration. J Chromatogr B Anal Technol Biomed Life Sci. 2010;878(11-12):861-7.

50. Oschmann R, Biber A, Lang F, Stumf H, Kunz K. Pharmacokinetics of beta-escin after administration of various Aesculus extract containing formulations. Pharmazie. 1996;51(8):577-81.

51. Greeske K, Pohlmann BK. Horse chestnut seed extract an effective therapy principle in general practice. Drug therapy of chronic venous insufficiency. Fortschr Med. 1996;114(15):196-200.

52. Ottillinger B, Greeske K. Rational therapy of chronic venous insufficiency chances and limits of the therapeutic use of horse-chestnut seeds extract. BMC Cardiovasc Disord. 2001;1:5.

53. Ernst E, Pittler MH, Stevinson C. Complementary/alternative medicine in dermatology: evidence-assessed efficacy of two diseases and two treatments. Am J Clin Dermatol. 2002;3(5): 341-8.

54. Pittler MH, Ernst E. Horse chestnut seed extract for chronic venous insufficiency. Cochrane Database Syst Rev. 2006;25(1):CD 003230 .

55. Guillaume M, Padioleau F. Veinotonic effect, vascular protection anti-inflammatory and free radical scavenging properties of horse chestnut extract. Arzneimittelforschung. 1994;44(1):25-35.

56. Kimura H, Ogawa S, Jisaka M, Kimura Y, Katsube T, Yokota K. Identification of novel saponins from edible seeds of Japanese horse chestnut (Aesculus turbinata Blume) after treatment with wooden ashes and their nutraceutical activity. J Pharm Biomed Anal. 2006;41(5):1657-65.

57. Hu JN, Zhu XM, Han LK, Saito M, Sun YS, Yoshikawa M, et al. Antiobesity effects of escins extracted from the seeds of Aesculus turbinata BLUME (Hippocastanaceae). Chem Pharm Bull (Tokyo). 2008;56(1):12-6.

58. Wetzel D, Menke W, Dieter R, Smasal V, Giannetti B, Bulitta M. Escin/diethylammonium salicylate heparin combination gels for the topical treatment of acute impact injuries: a randomised, double blind, placebo controlled, multicentre study. Br J Sports Med. 2002;36(3):183-8.

59. Grases F, Garcia-Gonzalez R, Redondo E, Costa-Bauza A, Simonet $\mathrm{BM}$, Sartini RP, et al. Effects of escin on indinavir crystallization time in the urine of patients with HIV-I infection: a multicenter, randomized, open-label, controlled, four-period crossover trial. Clin Ther. 2004;26:2045-55.

60. Arnould T, Janssens D, Michiels C, Remacle J. Effect of aescine on hypoxia-induced activation of human endothelial cells. Eur J Pharmacol. 1996;315(2):227-33.

61. Liu S, Wang H, Qiu C, Zhang J, Zhang T, Zhou W, et al. Escin inhibits lipopolysaccharide-induced inflammation in human periodontal ligament cells. Mol Med Rep. 2012;6(5):1150-4.

62. Xin W, Zhang L, Fan H, Jiang N, Wang T, Fu F. Escin attenuates acute lung injury induced by endotoxin in mice. Eur J Pharm Sci. 2011;42(1-2):73-80. 
63. Xin W, Zhang L, Sun F, et al. Escin exerts synergistic antiinflammatory effects with low doses of glucocorticoids in vivo and in vitro. Phytomedicine. 2011;18(4):272-7.

64. Xiao GM, Wei J. Effects of $\beta$-aescin on the expression of nuclear factor-kappa $B$ and tumor necrosis factor-alpha after traumatic brain injury in rats. J Zhejiang Univ Sci B. 2005;6(1):28-32.
65. Lindner I, Meier C, Url A, Unger H, Grassauer A, PrieschlGrassauer E, et al. Beta-escin has potent anti-allergic efficacy and reduces allergic airway inflammation. BMC Immunol. 2010;11:24. doi:10.1186/1471-2172-11-24. In this paper potential benefits of $\beta$-escin as anti-allergic agent have been summarized. 